University of Nebraska - Lincoln

DigitalCommons@University of Nebraska - Lincoln

USDA Forest Service / UNL Faculty Publications U.S. Department of Agriculture: Forest Service -National Agroforestry Center

2012

\title{
Midday stomatal conductance is more related to stem rather than leaf water status in subtropical deciduous and evergreen broadleaf trees
}

\author{
Yong-Jiang Zhang \\ Chinese Academy of Sciences, yongjiang_zhang@hks.harvard.edu \\ Frederick C. Meinzer \\ USDA Forest Service \\ Jin-Hua Qi \\ Chinese Academy of Sciences \\ Guillermo Goldstein \\ University of Miami, goldstein@bio.miami.edu \\ Kun-Fang Cao \\ Chinese Academy of Sciences, caokf@xtbg.ac.cn
}

Follow this and additional works at: https://digitalcommons.unl.edu/usdafsfacpub

Zhang, Yong-Jiang; Meinzer, Frederick C.; Qi, Jin-Hua; Goldstein, Guillermo; and Cao, Kun-Fang, "Midday stomatal conductance is more related to stem rather than leaf water status in subtropical deciduous and evergreen broadleaf trees" (2012). USDA Forest Service / UNL Faculty Publications. 234.

https://digitalcommons.unl.edu/usdafsfacpub/234

This Article is brought to you for free and open access by the U.S. Department of Agriculture: Forest Service -National Agroforestry Center at DigitalCommons@University of Nebraska - Lincoln. It has been accepted for inclusion in USDA Forest Service / UNL Faculty Publications by an authorized administrator of DigitalCommons@University of Nebraska - Lincoln. 


\title{
Midday stomatal conductance is more related to stem rather than leaf water status in subtropical deciduous and evergreen broadleaf trees
}

\author{
YONG-JIANG ZHANG ${ }^{1,2,3,4}$, FREDERICK C. MEINZER ${ }^{5}$, JIN-HUA QI $^{1,3}$, GUILLERMO GOLDSTEIN $^{2,6}$ \& \\ KUN-FANG CAO ${ }^{1}$
}

${ }^{1}$ Key Laboratory of Tropical Forest Ecology, Xishuangbanna Tropical Botanical Garden, Chinese Academy of Sciences, Mengla, Yunnan 666303, China, ${ }^{2}$ Department of Biology, University of Miami, PO Box 249118, Coral Gables, FL 33124, USA, ${ }^{3}$ Ailaoshan Station for Subtropical Forest Ecosystem Studies, Chinese Academy of Sciences, Jingdong 676200, China, ${ }^{4}$ Graduate University of Chinese Academy of Sciences, Beijing 100039, China, ${ }^{5}$ USDA Forest Service, Pacific Northwest Research Station, 3200 SW Jefferson Way, Corvallis, OR 97331, USA and ${ }^{6}$ Departamento de Ecologia, Genetica y Evolucion, Facultad de Ciencias Exactas y Naturales, Universidad de Buenos Aires, Ciudad Universitaria, Nuñez, Buenos Aires, Argentina

\begin{abstract}
Midday depressions in stomatal conductance $\left(g_{\mathrm{s}}\right)$ and photosynthesis are common in plants. The aim of this study was to understand the hydraulic determinants of midday $g_{s}$, the coordination between leaf and stem hydraulics and whether regulation of midday $g_{s}$ differed between deciduous and evergreen broadleaf tree species in a subtropical cloud forest of Southwest (SW) China. We investigated leaf and stem hydraulics, midday leaf and stem water potentials, as well as midday $g_{\mathrm{s}}$ of co-occurring deciduous and evergreen tree species. Midday $g_{s}$ was correlated positively with midday stem water potential across both groups of species, but not with midday leaf water potential. Species with higher stem hydraulic conductivity and greater daily reliance on stem hydraulic capacitance were able to maintain higher stem water potential and higher $g_{\mathrm{s}}$ at midday. Deciduous species exhibited significantly higher stem hydraulic conductivity, greater reliance on stem capacitance, higher stem water potential and $g_{\mathrm{s}}$ at midday than evergreen species. Our results suggest that midday $g_{\mathrm{s}}$ is more associated with midday stem than with leaf water status, and that the functional significance of stomatal regulation in these broadleaf tree species is probably for preventing stem xylem dysfunction.
\end{abstract}

Key-words: leaf phenology; midday depression in photosynthesis; stem hydraulic capacitance; stem water potential; stomatal regulation.

\section{INTRODUCTION}

Midday depression in photosynthetic gas exchange is commonly observed in plants (Tenhunen, Pearcy \& Lange 1987; Koch, Amthor \& Goulden 1994; Kosugi \& Matsuo 2006;

Correspondence: K-F.Cao. E-mail: caokf@xtbg.ac.cn; G. Goldstein. Fax: +1305 284 3039; e-mail: goldstein@bio.miami.edu
Tucci et al. 2010), and down-regulation of stomatal conductance $\left(g_{\mathrm{s}}\right)$ is one of the major contributing factors (Schulze et al.1974; Raschke \& Resemann 1986; Iio et al. 2004; Grassi et al.2009). Although the trigger of stomatal closure is not fully understood, leaf water potential $\left(\Psi_{\mathrm{L}}\right)$ is one of the major factors in stomatal regulation because stomatal aperture directly responds to guard cell turgor (Franks et al. 1995). However, the interspecific relationship between midday $\Psi_{\mathrm{L}}$ and midday $g_{\mathrm{s}}$ has not been well established, and the mechanism by which stomata respond to and control $\Psi_{\mathrm{L}}$ is unclear (Brodribb \& Holbrook 2003; Meinzer et al. 2009). Notably, the ability of a plant to maintain high $\Psi_{\mathrm{L}}$ during active transpiration is related to the plant hydraulic system: those species with high water transport would be able to replace transpirational water loss more quickly and therefore maintain higher $\Psi_{\mathrm{L}}$ (Brodribb, Feild \& Jordan 2007; Campanello, Gatti \& Goldstein 2008; Zhang \& Cao 2009). Consequently, a positive relationship between water transport and maximum photosynthetic rate has been found in different plant taxonomic groups and different ecosystems (Brodribb \& Feild 2000; Santiago et al. 2004; Brodribb et al. 2007; Campanello et al. 2008; Zhang \& Cao 2009). The midday $g_{\mathrm{s}}$ of a plant could also be related to plant hydraulic characteristics: plants with higher water transport at midday can maintain better leaf water status during this daytime period, and consequently experience less depression in midday $g_{s}$. However, this hydraulic determinant of midday $g_{\mathrm{s}}$ has not been well investigated.

Stomatal regulation is responsible for controlling the stem xylem water potential ( $\left.\Psi_{\text {ST }}\right)$ during the day (Meinzer et al. 2009). Decreased $g_{s}$ at midday slows down further water loss, consequently, it has an adaptive significance in protecting the plant vascular system from xylem dysfunction. Recent studies have shown that diurnal depression in leaf hydraulic conductance is common in many plant species (Bucci et al. 2003; Brodribb \& Holbrook 2004a; Zhang et al. 2009; Johnson et al. 2009a, 2011a; Zufferey et al. 
2011), while a diurnal decrease in stem hydraulic conductivity has been observed only in very few species (Zwieniecki \& Holbrook 1998; Melcher et al. 2001). Since leaf hydraulic conductance decreases and recovers diurnally in many species, the major function of stomatal regulation is not likely to be protection of the leaf hydraulic system from dysfunction in those species. Rather, the significance of diurnal stomatal regulation is probably to maintain $\Psi_{\mathrm{ST}}$ in the range that will avoid stem xylem embolism during the day (Meinzer et al. 2009). In fact, midday depression in $K_{\text {leaf }}$ itself is thought to be a mechanism to magnify the signal triggered by water deficits, resulting in rapid stomatal closure (Brodribb \& Holbrook 2004b), which slows down further dehydration of stems and roots. Under the assumption that the down-regulation in $K_{\text {leaf }}$ and $g_{\mathrm{s}}$ is mainly to prevent stem xylem dysfunction, we suggest that midday $g_{\mathrm{s}}$ should be more related to $\Psi_{\mathrm{ST}}$ rather than to $\Psi_{\mathrm{L}}$.

The relationship between $g_{\mathrm{s}}$ and $\Psi_{\mathrm{ST}}$ could be mediated by stem hydraulic capacitance (Meinzer et al. 2008, 2009). Stem water storage plays an important role in mitigating diurnal water deficits caused by transpirational water loss (Goldstein et al. 1998; Scholz et al. 2007), and may reduce diurnal fluctuation in $\Psi_{\mathrm{ST}}$ (Meinzer et al. 2008). Stem hydraulic capacitance strongly determines the midday stem and leaf water status (Meinzer et al.2003, 2008; Scholz et al. 2007), and consequently trees with higher water storage capacities are able to maintain maximum transpiration rates for a longer period of time during the day (Goldstein et al. 1998). Therefore, stem hydraulic capacitance needs to be considered in analysing the relationship between midday $g_{\text {s }}$ and leaf/stem water potentials. Notably, two deciduous species were reported to have higher stem hydraulic capacitance than two co-occurring evergreen species in an Australian dry forest (Choat et al. 2005). If this difference in hydraulic capacitance between deciduous and evergreen species reflects a general pattern across other types of ecosystems, deciduous species with potentially higher hydraulic capacitance may maintain higher midday leaf and stem water potentials, and consequently higher midday $g_{\mathrm{s}}$ than evergreen species.

We studied leaf and stem hydraulics, midday stem and leaf water status, and midday leaf $g_{\mathrm{s}}$ of 14 co-occurring broadleaf tree species (10 evergreen and four deciduous species) in a subtropical cloud forest with abundant moisture in Southwest (SW) China. The objectives of the present study were (1) to determine the hydraulic determinants of midday depression in photosynthetic gas exchange, (2) to clarify the hydraulic regulation of midday stem and leaf water potentials and (3) to characterize the difference in midday hydraulic and stomatal performance between deciduous and evergreen broadleaf tree species.

\section{MATERIALS AND METHODS}

\section{Study site}

This study was carried out in an evergreen broadleaf forest at the Ailaoshan Station for Subtropical Evergreen
Broadleaf Forest Ecosystem Studies $\left(24^{\circ} 32^{\prime} \mathrm{N}, 101^{\circ} 01^{\prime} \mathrm{E}\right.$, elevation $2460 \mathrm{~m}$ ), located on Ailao Mountain, Jingdong County, Yunnan Province, SW China. The station is a member of the Chinese Ecosystem Research Network (CERN), and a member of the Chinese National Ecosystem Observation and Research Network (CEORN). Average annual temperature at the study site is $11.3{ }^{\circ} \mathrm{C}$ and average annual precipitation is $1931 \mathrm{~mm}$ (Qiu \& Xie 1998). Because of abundant moisture and persistent cloud cover, this forest has also been described as a subtropical cloud forest. The soils of the study site are loamy yellow-brown soils. The surface soil layer $(0-15 \mathrm{~cm})$ contains $12.15 \%$ organic matter, $0.42 \%$ total $\mathrm{N}$ and $0.16 \%$ total P (Qiu \& Xie 1998). The physiological measurements were carried out at the end of the rainy season (September to early November) in 2011, when the deciduous species were about one to 2 months away from leaf shedding. We performed the measurements in this time period because soil water potentials were still close to zero, while sunny days were frequent enough to complete the measurements. Sunny days are rare in the middle of the rainy season owing to frequent rain and fog events. Fourteen co-occurring broadleaf tree species were selected, including 10 evergreen species and four deciduous species (Table 1). Sun-exposed trees (2 to $3 \mathrm{~m}$ high) at the forest edge were used to perform the physiological measurements to avoid shading effects.

\section{Leaf and stem water potentials and stomatal conductance}

For each species, six newest fully developed mature leaves from sun-exposed terminal branches of six different individuals were selected to measure leaf water potential $\left(\Psi_{\mathrm{L}}\right)$ and stomatal conductance $\left(g_{\mathrm{s}}\right)$. Leaf water potential was measured with a pressure chamber (PMS, Albany, OR, USA). Stem xylem water potential ( $\left.\Psi_{\mathrm{ST}}\right)$ was estimated by measuring the water potential of a non-transpiring (bagged) leaf (Begg \& Turner 1970; Nardini, Tyree \& Salleo 2001; Sack, Cowan \& Holbrook 2003; Bucci et al.2004). Six sun-exposed mature leaves per species were pre-bagged at late afternoon of the previous day for $\Psi_{\mathrm{ST}}$ measurement. Pre-dawn samples were collected from the tree in the field at 600 to $700 \mathrm{~h}$, while midday samples were collected at 1230 to $1430 \mathrm{~h}$.

Daily maximum and midday leaf stomatal conductance $\left(g_{\mathrm{s}}\right)$ was measured with a portable photosynthesis measurement system (LI-6400, Li-Cor, Lincoln, NE, USA) under ambient conditions on typical sunny days. Daily maximum stomatal conductance was measured at 900 to $1100 \mathrm{~h}$, while minimum/midday $g_{\mathrm{s}}$ was measured at 1230 to $1430 \mathrm{~h}$. Ambient temperature was around $19^{\circ} \mathrm{C}$ in the morning, and was around $22{ }^{\circ} \mathrm{C}$ during the midday period. Ambient atmospheric vapour pressure deficit (VPD) was around $0.9 \mathrm{kPa}$ in the morning, and $1.4 \mathrm{kPa}$ at midday.

\section{Stem relative water content and capacitance}

For stem relative water content (RWC) measurement, stem sections about $15 \mathrm{~cm}$ long $(n=6)$ were cut from different 


\begin{tabular}{|c|c|c|c|}
\hline Species & Code & Family & $\begin{array}{l}\text { Leaf } \\
\text { phenology }\end{array}$ \\
\hline Lithocarpus jingdongensis Y. C. Hsu \& H. J. Qian & $\mathrm{LJ}$ & Fagaceae & Evergreen \\
\hline Symplocos sumuntia D. Don & SS & Symplocaceae & Evergreen \\
\hline Schima noronhae Reinw. ex Blume & SN & Theaceae & Evergreen \\
\hline Vaccinium delavayi Franch & VD & Vacciniaceae & Evergreen \\
\hline Manglietia insignis Blume & MI & Magonoliaceae & Evergreen \\
\hline $\begin{array}{l}\text { Lithocarpus hypoviridis Y. C. Hsu, B. S. Sun \& } \\
\text { H. J. Qian }\end{array}$ & LH & Fagaceae & Evergreen \\
\hline Ternstroemia gymnanthera Sprague & TG & Theaceae & Evergreen \\
\hline Lyonia ovalifolia Drude var. lanceolata Hand.-Mazz. & $\mathrm{LOv}$ & Ericaceae & Evergreen \\
\hline Hartia sinensis Dunn & HS & Theaceae & Evergreen \\
\hline Illicium macranthum A. C. Smith & IM & Illiciaceae & Evergreen \\
\hline Betula alnoides Hamilt. & BA & Betulaceae & Deciduous \\
\hline Populus yunnanensis Dode & PY & Salicaceae & Deciduous \\
\hline Lyonia ovalifolia Drude var. ovalifolia & LO & Ericaceae & Deciduous \\
\hline Clethra brammerianaHand.-Mazz. & $\mathrm{CB}$ & Clethraceae & Deciduous \\
\hline
\end{tabular}

Table 1. Fourteen broadleaf tree species studied in the present study, their species code used, family and leaf phenology individuals in the field, immediately sealed in a plastic bag and then transported to the laboratory. Stem samples were collected between 600 and $700 \mathrm{~h}$ and again between 1230 and $1430 \mathrm{~h}$. A segment about $5 \mathrm{~cm}$ long (with a diameter about $1 \mathrm{~cm}$ ) was cut from the middle of the stem section and used to determine the RWC. After determining the fresh weight (FW), the segment was submerged under water for $48 \mathrm{~h}$ for rehydration. After determining the saturated weight (SW), the stem segment was oven-dried for $48 \mathrm{~h}$ to determine the dry weight (DW). Stem RWC was then calculated as

$$
\mathrm{RWC}=(\mathrm{FW}-\mathrm{DW}) /(\mathrm{SW}-\mathrm{DW}) \times 100 \%
$$

Stem hydraulic capacitance over the $\Psi_{\mathrm{ST}}$ range during the day $\left(C_{\text {day }}\right)$ was determined as

$$
C_{\text {day }}=\Delta \mathrm{RWC} / \Delta \Psi=\left(\mathrm{RWC}_{\mathrm{p}}-\mathrm{RWC}_{\mathrm{m}}\right) /\left(\Psi_{\mathrm{ST}-\mathrm{p}}-\Psi_{\mathrm{ST}-\mathrm{m}}\right)
$$

Where $\mathrm{RWC}_{\mathrm{p}}$ is the pre-dawn stem RWC, $\mathrm{RWC}_{\mathrm{m}}$ is the midday stem RWC, $\Psi_{\text {ST-p }}$ is the pre-dawn stem water potential, and $\Psi_{\text {ST-m }}$ is the midday stem water potential. Since all the midday $\Psi_{\text {ST-m }}$ were quite high, and more positive than the typical stem tissue turgor loss point of trees (Meinzer et al. 2008), it was assumed that stem tissue did not lose turgor during the midday. Stem $C_{\text {day }}$ was then normalized to weight of water per volume per $\mathrm{MPa}\left(\mathrm{kg} \mathrm{m}^{-3} \mathrm{MPa}^{-1}\right)$ by multiplying the weight of water at saturation per unit sapwood volume. Since stem $C_{\text {day }}$ used in the present study is measured over the range of $\Psi_{\mathrm{ST}}$ during the day, it is a measure of daily reliance on capacitance, and not necessarily comparable to the hydraulic capacitance as determined in other studies (e.g. Meinzer et al. 2003).

\section{Wood density}

Wood (sapwood) density of terminal branches was measured for six individuals per species. Stem section samples were taken from the terminal branches, sealed in plastic bags, and transported to the laboratory immediately. After removing the bark and pith with a razor blade, the cores were weighed, placed in water in a small graduated cylinder to determine the volume and then oven-dried to a constant mass and weighed again to obtain the dry mass. Density was then determined by dividing the dry mass by the volume of the sample.

\section{Stem hydraulic conductivity and leaf hydraulic conductance}

Stem hydraulic conductivity was measured using a hydraulic conductivity measurement system (Tyree \& Sperry 1989). Branches about $1.5 \mathrm{~m}$ long were cut from the trees $(n=6)$ in the early morning, placed in black plastic bags and then transported to the lab for measurements. Maximum vessel length in the studied tree species ranged from 50 to $131 \mathrm{~cm}$. Immediately after arriving at the laboratory, stem segments about $70 \mathrm{~cm}$ long were re-cut under water and attached to the hydraulic conductivity measurement system (Tyree \& Sperry 1989). An attempt has been made to use stem segment as long as possible with branch junctions and leaf scars avoided. The downstream ends of the stems were connected to measuring pipettes and the flow rates were volumetrically monitored. Following a short equilibration period, water flow generated by a constant hydraulic head of $70 \mathrm{~cm}$, was measured. Distilled/de-gassed water was used as the perfusion fluid. Hydraulic conductivity $\left(\mathrm{kg} \mathrm{m} \mathrm{s}^{-1} \mathrm{MPa}^{-1}\right)$ was calculated as

$$
K_{\mathrm{h}}=J_{\mathrm{v}} /(\Delta P / \Delta X)
$$

Where $J_{\mathrm{v}}$ is the flow rate through the stem segment $\left(\mathrm{kg} \mathrm{s}^{-1}\right.$; converted from $\mathrm{mL} \mathrm{s}^{-1}$ ) and $\Delta P / \Delta X$ is the pressure gradient across the stem segment $\left(\mathrm{MPa} \mathrm{m}^{-1}\right)$. Specific hydraulic conductivity $\left(K_{\mathrm{s}} ; \mathrm{kg} \mathrm{m}^{-1} \mathrm{~s}^{-1} \mathrm{MPa}^{-1}\right)$ was obtained as the ratio of $K_{\mathrm{h}}$ and the cross-sectional area of the active xylem. Active xylem area was distinguished from heartwood by pushing dye through the stem sections.

Midday leaf hydraulic conductance $\left(K_{\text {leaf }}\right)$ was measured with the in situ evaporation method (Sack et al. 2003; Sellin 
\& Kupper 2007) at 1230 to $1430 \mathrm{~h}$. Leaf transpiration rate $(E)$ was measured with the portable photosynthetic measurement system (LI-6400, Li-Cor) under ambient conditions. Measurements were done within 1 or 2 min after leaves were enclosed in the cuvette to minimize the difference in environmental conditions between the cuvette and ambient atmosphere. The driving force was the difference between stem water potential $\left(\Psi_{\mathrm{ST}}\right)$ and leaf water potential $\left(\Psi_{\mathrm{L}}\right)$, measured as described above. Midday $K_{\text {leaf }}$ was then calculated as

$$
K_{\text {leaf }}=E / \Delta \Psi=E /\left(\Psi_{\mathrm{ST}}-\Psi_{\mathrm{L}}\right)
$$

Leaf hydraulic conductance was then corrected for the effects of temperature on the viscosity of water by standardizing to $20^{\circ} \mathrm{C}$ (Yang \& Tyree 1993; Sack et al.2002; Brodribb et al. 2007). This method may have a disadvantage because the environmental conditions of the enclosed cuvette could be slightly different from the field conditions (Sellin \& Kupper 2007), but it also has an advantage in avoiding the effects of detaching the leaves from the plants.

\section{Data analysis}

The differences between maximum and midday $g_{\text {s }}$, between midday $\Psi_{\mathrm{ST}}$ and $\Psi_{\mathrm{L}}$, and between pre-dawn and midday stem RWC were tested by the one-way analysis of variance (AnOva). The differences in mean stem capacitance, $K_{\mathrm{s}}$, midday stem or leaf water potential, as well as midday and maximum $g_{\mathrm{s}}$ between evergreen and deciduous species were tested by the Mann-Whitney $U$-test. Linear or exponential regressions were fitted to the relationships among functional traits (as shown in the Figures).

\section{RESULTS}

Eleven of the fourteen broadleaf tree species significantly down-regulated leaf stomatal conductance $\left(g_{\mathrm{s}}\right)$ at midday, while three species did not show a significant midday decrease in $g_{\mathrm{s}}$ compared with daily maximum $g_{\mathrm{s}}$ (Fig. 1a). Deciduous species had significantly higher maximum and midday $g_{\mathrm{s}}$, compared with evergreen species (Fig. 1a; Table 2). Midday leaf water potential $\left(\Psi_{\mathrm{L}}\right)$ of the 14 tree species ranged from -0.55 to $-1.84 \mathrm{MPa}$, while midday stem water potential $\left(\Psi_{\mathrm{ST}}\right)$ ranged from -0.12 to $-0.50 \mathrm{MPa}$ (Fig. 1b). The deciduous tree species had significantly lower midday $\Psi_{\mathrm{L}}$, but significantly higher $\Psi_{\mathrm{ST}}$ than the evergreen species (Fig. 1b; Table 2). Midday $\Psi_{\mathrm{L}}$ was significantly more negative than $\Psi_{\mathrm{ST}}$ in all the species (Fig. 1b). All 14 species showed midday declines in stem RWC, but these were only significant in eight of the species (Fig. 1c).

No significant correlation was found between midday $g_{\mathrm{s}}$ and midday $\Psi_{\mathrm{L}}$ across species (Fig. 2a). In contrast, a significant, positive correlation was found between midday $g_{\mathrm{s}}$ and midday $\Psi_{\mathrm{ST}}$ (Fig. 2b). Midday $\Psi_{\mathrm{ST}}$ and midday $\Psi_{\mathrm{L}}$ were not significantly correlated (data not shown). Midday $g_{\mathrm{s}}$ and daily maximum $g_{s}$ were positively correlated with stem xylem area specific hydraulic conductivity $\left(K_{\mathrm{s}}\right.$; Fig. 2 c,d).
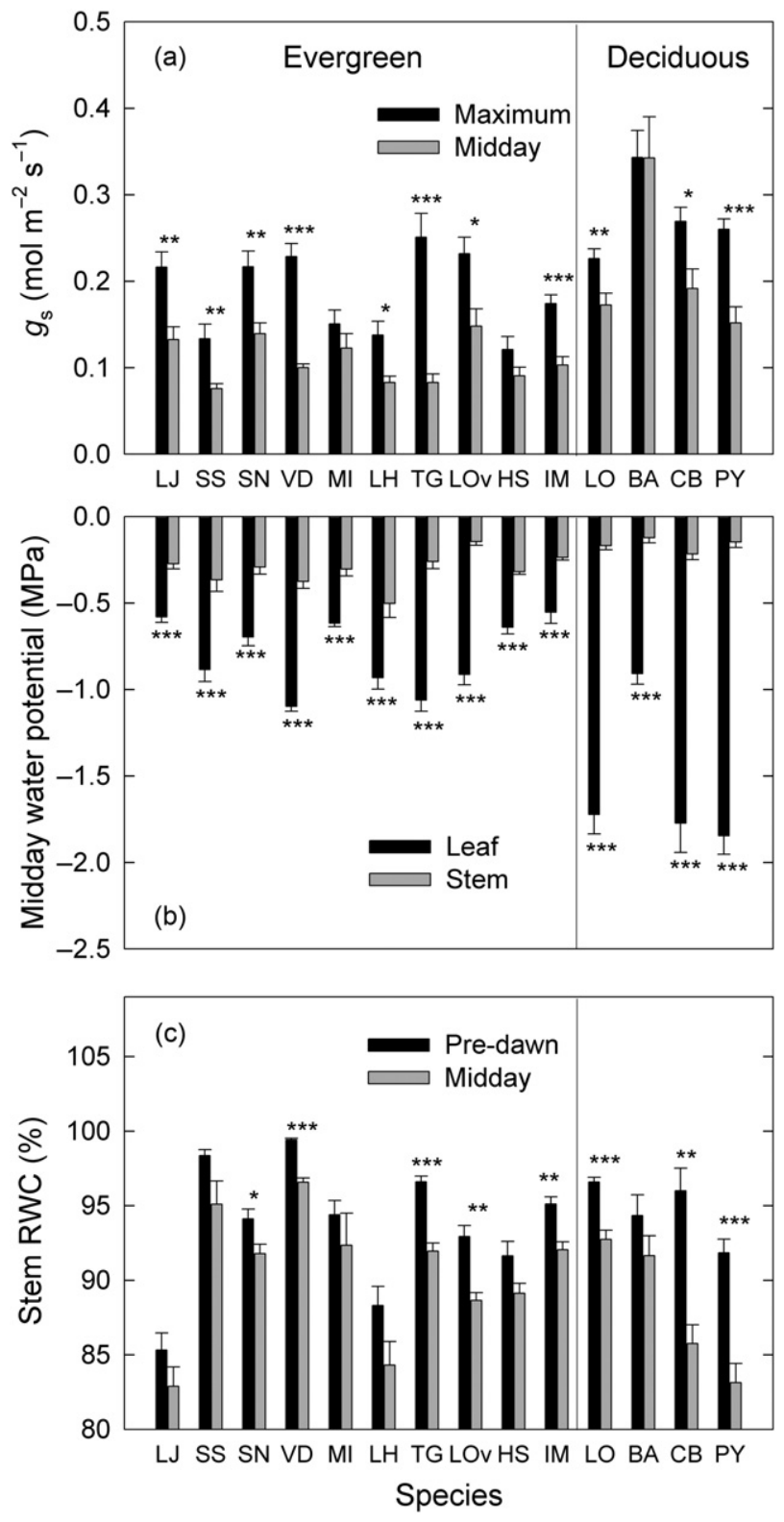

Figure 1. (a) Daily maximum and midday leaf stomatal conductance $\left(g_{\mathrm{s}}\right)$; (b) midday leaf water potential and midday stem water potential; and (c) pre-dawn and midday stem relative water content (RWC) of 14 broadleaf tree species from Ailao Mountain. $* P<0.05 ; * * P<0.01$; $* * * P<0.001$. Species codes are in Table 1.

Deciduous species had significantly higher $K_{\mathrm{s}}$ than the evergreen species (Fig. 2c; Table 2). The relationship between maximum $g_{\mathrm{s}}$ and $K_{\mathrm{s}}$ (Fig. 2c) was not significant if the data of BA was not included $\left(r^{2}=14, P=0.21\right)$.

Midday $\Psi_{\text {ST }}$ was positively correlated with stem hydraulic capacitance over the $\Psi_{\mathrm{ST}}$ range during the day $\left(C_{\mathrm{day}}\right.$; Fig. 3a), negatively correlated with wood density (Fig. 3b), and positively correlated with $K_{\mathrm{s}}$ (Fig. 3c) across the 14 tree species. The relationship between midday $\Psi_{\mathrm{ST}}$ and $K_{\mathrm{s}}$ (Fig. 3c) was not significant if the data of BA was not 
Table 2. The mean stem capacitance over the $\Psi_{\mathrm{ST}}$ during the day $\left(C_{\mathrm{day}}\right)$, specific hydraulic conductivity $(K \mathrm{~s})$, midday stem water potential $\left(\Psi_{\mathrm{ST}}\right)$ or leaf water potential $\Psi_{\mathrm{L}}$, as well as midday and maximum stomatal conductance $\left(g_{\mathrm{s}}\right)$ of evergreen and deciduous species. The data are means \pm SE. The $P$ values are from Mann-Whitney $U$-test between evergreen $(n=10)$ and deciduous species $(n=4)$

\begin{tabular}{lllllll}
\hline & $\begin{array}{l}C_{\text {day }} \\
\mathrm{kg} \mathrm{m}^{-3} \mathrm{MPa}^{-1}\end{array}$ & $\begin{array}{l}K_{\mathrm{s}} \\
\mathrm{kg} \mathrm{m}^{-1} \mathrm{~s}^{-1} \mathrm{MPa}^{-1}\end{array}$ & $\begin{array}{l}\text { Midday } \Psi_{\mathrm{ST}} \\
\mathrm{MPa}\end{array}$ & $\begin{array}{l}\text { Midday } \Psi_{\mathrm{L}} \\
\text { MPa }\end{array}$ & $\begin{array}{l}\text { Midday } g_{\mathrm{s}} \\
\mathrm{mol} \mathrm{m}^{-2} \mathrm{~s}^{-1}\end{array}$ & $\begin{array}{l}\text { Maximum } g_{\mathrm{s}} \\
\mathrm{mol} \mathrm{m}^{-2} \mathrm{~s}^{-1}\end{array}$ \\
\hline Evergreen & $94 \pm 23$ & $1.38 \pm 0.12$ & $-0.31 \pm 0.03$ & $-0.79 \pm 0.06$ & $0.11 \pm 0.01$ & $0.19 \pm 0.02$ \\
Deciduous & $324 \pm 115$ & $2.48 \pm 0.44$ & $-0.16 \pm 0.02$ & $-1.56 \pm 0.22$ & $0.21 \pm 0.04$ & $0.27 \pm 0.02$ \\
$P$ & 0.011 & 0.016 & 0.016 & 0.024 & 0.005 & 0.016 \\
\hline
\end{tabular}

included $\left(r^{2}=16, P=0.18\right)$. On the other hand, $\Psi_{\mathrm{L}}$ was negatively correlated with $C_{\text {day }}$ (Fig. 4a) and change in stem RWC (pre-dawn RWC - midday RWC; Fig. 4b) and positively correlated with midday leaf hydraulic conductance (Fig. 4c). Percent midday decrease in $g_{\mathrm{s}}$ was positively correlated with wood density across the studied tree species (Fig. 5a). The difference between $\Psi_{\mathrm{ST}}$ and $\Psi_{\mathrm{L}}$ in midday was positively correlated with $C_{\text {day }}$ (Fig. 5b).

\section{DISCUSSION}

In spite of the commonness of midday depression in stomatal conductance $\left(g_{\mathrm{s}}\right)$ and its impact on leaf photosynthetic gas exchange and plant productivity, the hydraulic determinants of midday $g_{\mathrm{s}}$ are not well understood. Previous studies have focused on the role of hydraulics in determining maximum $g_{\mathrm{s}}$ and photosynthetic rate (Brodribb \&
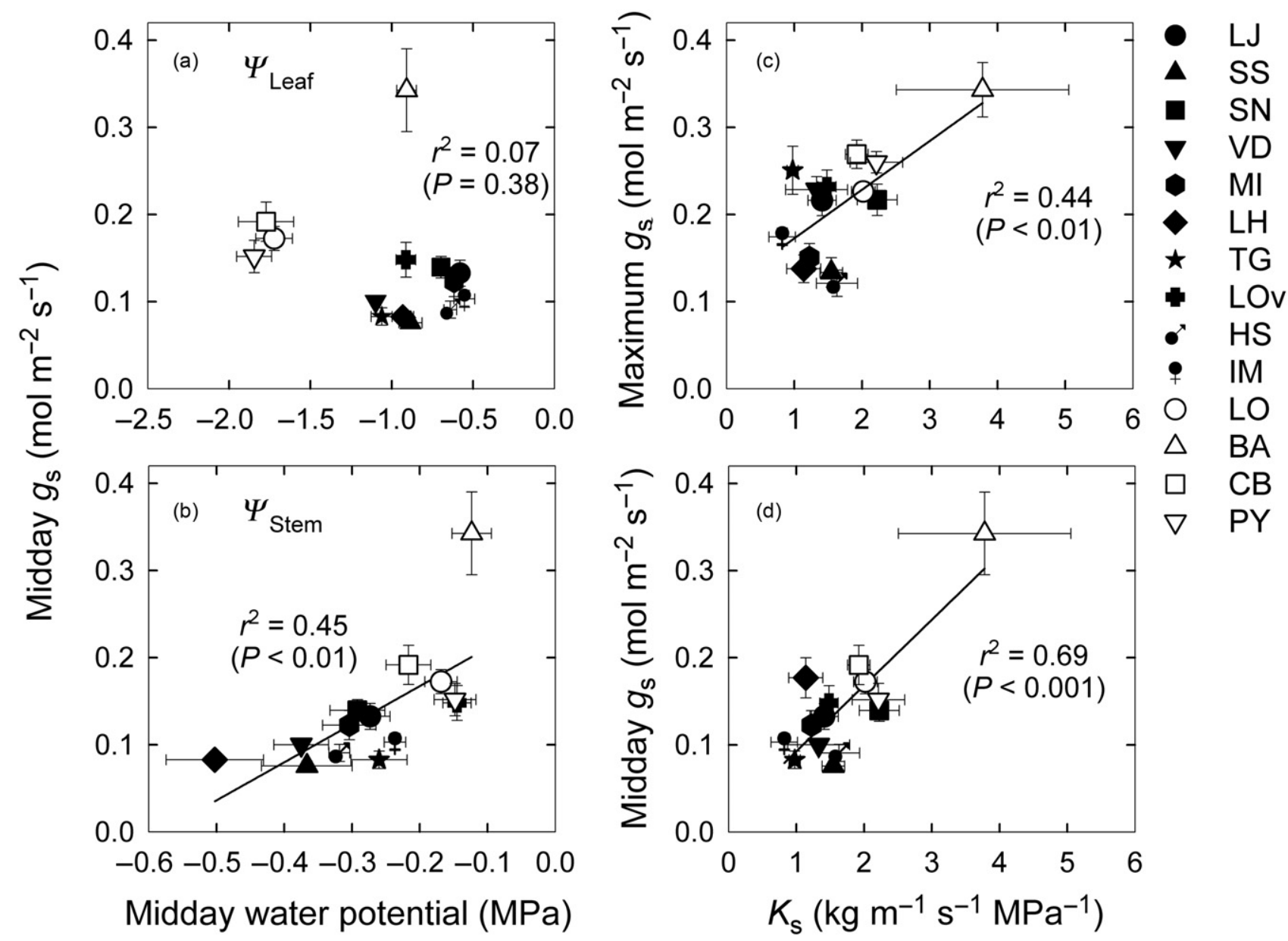

Figure 2. (a) Midday leaf stomatal conductance $\left(g_{\mathrm{s}}\right)$ in relation to midday leaf water potential (a) and midday stem water potential (b); and stem xylem area specific hydraulic conductivity $\left(K_{\mathrm{s}}\right)$ in relation to daily maximum $g_{\mathrm{s}}(\mathrm{c})$ and midday $g_{\mathrm{s}}(\mathrm{d})$ across the evergreen (filled symbols) and deciduous tree (open symbols) species. Solid lines are linear regressions fitted to the data. Species codes are in Table 1. 

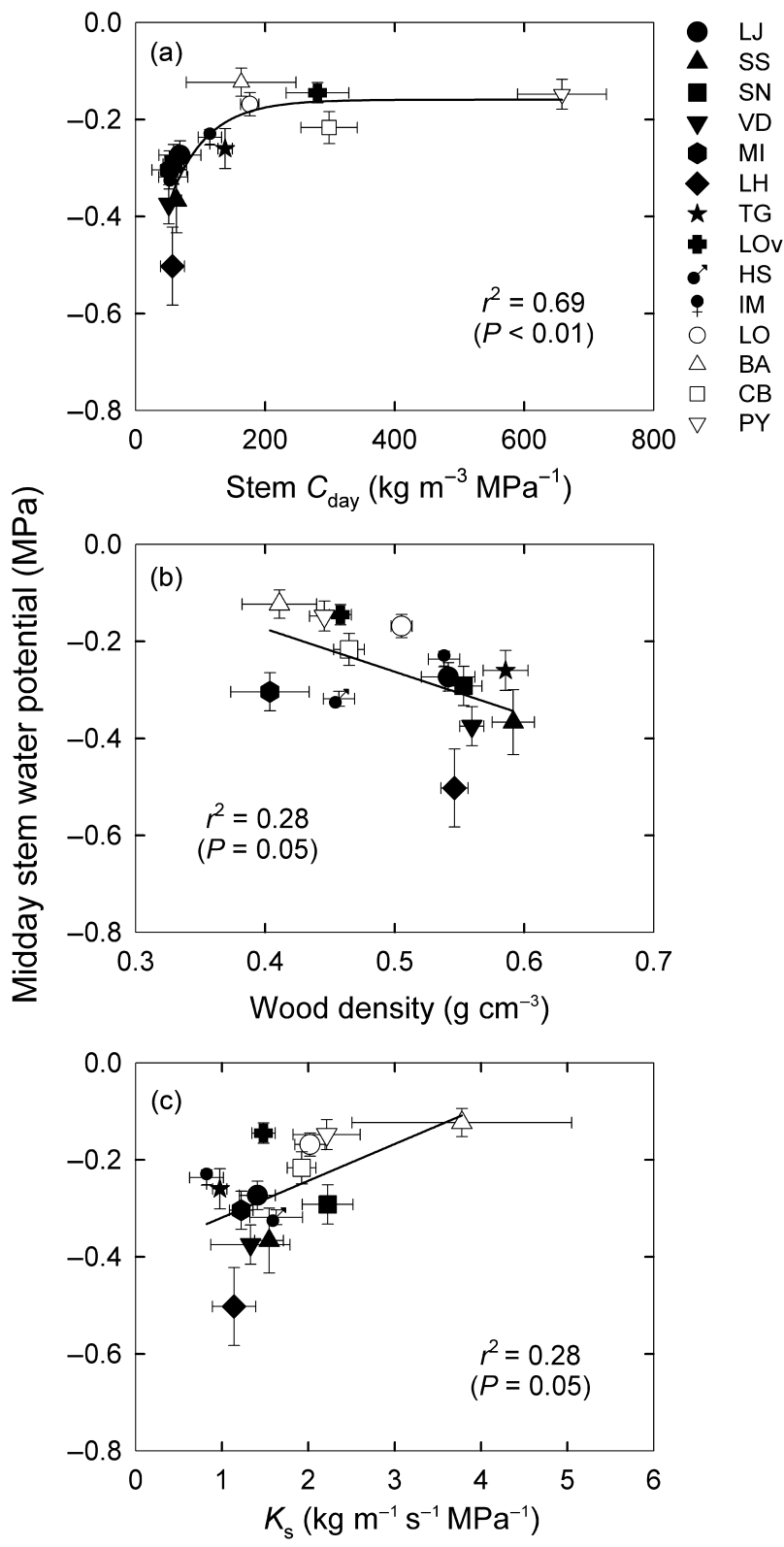

Figure 3. Midday stem water potential in relation to stem hydraulic capacitance over the $\Psi_{\mathrm{ST}}$ range during the day $\left(C_{\text {day }} ; \mathrm{a}\right)$, wood density (b) and stem xylem area specific hydraulic conductivity $\left(K_{\mathrm{s}} ; \mathrm{c}\right)$. Solid lines are linear $(\mathrm{b} ; \mathrm{c})$ or exponential $(\mathrm{a})$ regressions fitted to the data. Species codes are in Table 1, filled symbols for evergreen species, and open symbols for deciduous species.

Feild 2000; Santiago et al. 2004; Brodribb et al. 2007; Campanello et al. 2008; Zhang \& Cao 2009), but not in maintaining $g_{\mathrm{s}}$ at midday. The 14 broadleaf species studied varied strongly in midday $g_{\mathrm{s}}$. Hydraulic properties could be an important determinant of stomatal sensitivity to VPD (Franks \& Farquhar 1999). By studying the interspecific correlations among stem-specific hydraulic conductivity $\left(K_{\mathrm{s}}\right)$, daily reliance on hydraulic capacitance $\left(C_{\text {day }}\right)$, midday stem xylem water potential ( $\left.\Psi_{\mathrm{ST}}\right)$, leaf water potential $\left(\Psi_{\mathrm{L}}\right)$ and $g_{\mathrm{s}}$ in 14 co-occurring broadleaf species, our study reveals some insights concerning the hydraulic determinants of midday $g_{\mathrm{s}}$, the coordination between stem and leaf hydraulics, and the adaptive significance of midday depression in $g_{s}$. Different tree species may have different rooting depth, and may experience different soil water potentials, which will influence stomatal behaviour. However, our measurements were performed at the end of the rainy season when water potentials of the different soil layers were close to zero. Therefore, species-specific difference in
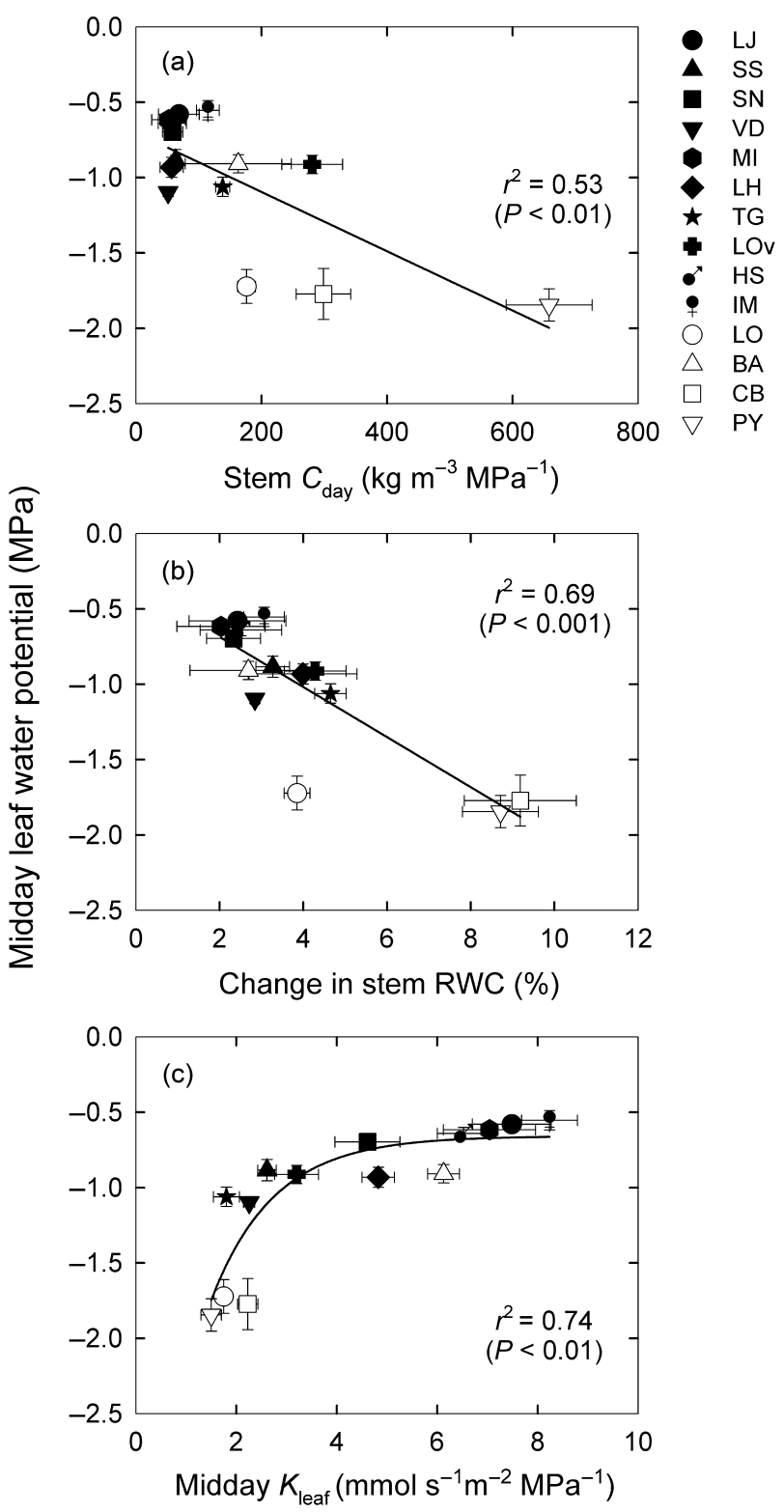

Figure 4. Midday leaf water potential in relation to stem hydraulic capacitance over the $\Psi_{\mathrm{ST}}$ range during the day $\left(C_{\mathrm{day}} ; \mathrm{a}\right)$, change in stem relative water content (b) and midday leaf hydraulic conductance $(\mathrm{c})$. Solid lines are linear $(\mathrm{a} ; \mathrm{b})$ or exponential (c) regressions fitted to the data. Species codes are in Table 1, filled symbols for evergreen species and open symbols for deciduous species. 

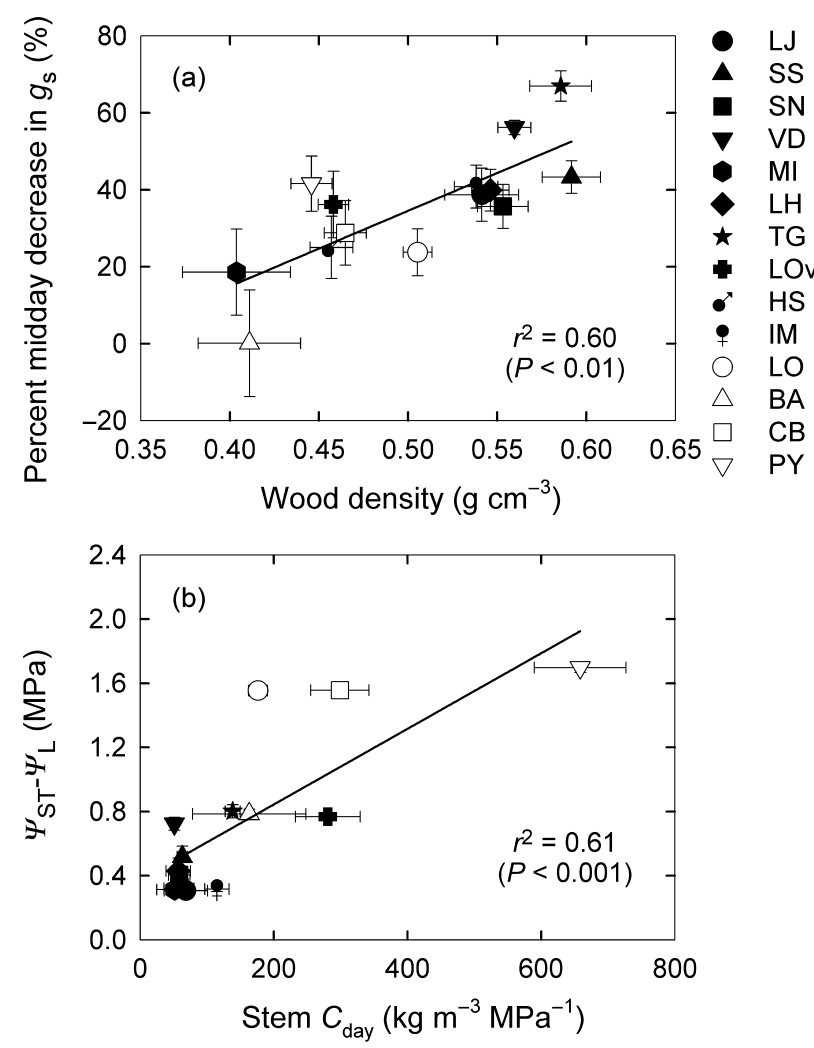

Figure 5. Percent midday decrease in stomatal conductance $\left(g_{\mathrm{s}}\right)$ in relation to wood density (a), and the difference in midday stem and leaf water potential $\left(\Psi_{\mathrm{ST}}-\Psi_{\mathrm{L}}\right)$ in relation to stem hydraulic capacitance over the $\Psi_{\mathrm{ST}}$ range during the day $\left(C_{\mathrm{day}} ; \mathrm{b}\right)$. Species codes are in Table 1, filled symbols for evergreen species and open symbols for deciduous species.

$g_{\text {s }}$ should be explained by species-specific functional traits rather than soil water availability in the rooting zone.

\section{Hydraulic determinants of midday stomatal conductance}

Our results show that midday $g_{\mathrm{s}}$ of the 14 broadleaf species studied was closely related to midday stem water status rather than to leaf water status (Fig. 2). That is, species with a great capacity to avoid high stem water deficits during periods of high transpiration tended to have a relatively risky stomatal strategy and maintained higher midday $g_{s}$. Species with low wood density, therefore high hydraulic capacity (Scholz et al. 2007), appeared to have lower midday depression in $g_{\mathrm{s}}$ (Fig. 5a), suggesting that stem water storage plays an important role in maintaining midday $g_{\mathrm{s}}$. On the other hand, the close relationship between $\Psi_{\mathrm{ST}}$ and $g_{\mathrm{s}}$ suggests that the primary functional significance of stomatal closure during the day is probably to protect the stem xylem rather than the leaf hydraulic system, although the direct internal signal that triggers stomatal closure probably involves leaf level traits such as guard cell turgor (Franks et al. 1995) or leaf hydraulic conductance $\left(K_{\text {leaf }}\right.$; Brodribb \& Holbrook 2003).
The lack of coordination between midday $g_{\mathrm{s}}$ and midday $\Psi_{\mathrm{L}}$ in the present study (Fig. $2 \mathrm{a}$ ) was consistent with the diurnal decline and recovery in $K_{\text {leaf }}$ reported in several species and suggests that stomatal regulation of $\Psi_{\mathrm{L}}$ does not avoid embolism in leaves of these species. Several studies have shown that diurnal decrease and recovery in leaf hydraulic conductance is common in plants (Bucci et al. 2003; Brodribb \& Holbrook 2004a; Zhang et al. 2009; Johnson et al. 2009a, 2011a; Zufferey et al. 2011), and that embolism is the main process explaining the decrease in $K_{\text {leaf }}$ (Lo Gullo et al. 2003; Woodruff et al. 2007; Johnson et al. 2009b, 2011b). Therefore, the primary functional significance of stomatal closure during the day is probably not to prevent leaf embolism in these species. Embolism refilling in leaves with relatively smaller xylem vessels compared with the stems probably costs less energy because the hydrostatic pressures required for embolism refilling depend upon the conduit size (Hacke \& Sperry 2003), and also leaf xylem is in close proximity to the sugars recently produced by photosynthesis, which apparently are required for embolism refilling under negative pressure (Zwieniecki \& Holbrook 2009; Nardini, Lo Gullo \& Salleo 2011). Notably, stomatal closure is closely coordinated with the initiation of leaf cavitation (Brodribb \& Holbrook 2003; Brodribb et al. 2003, Brodribb \& Holbrook 2004b), and leaf cavitation may amplify the signal of water deficits to further stimulate stomatal closure to inhibit further water loss in stems (Brodribb \& Holbrook 2004b). In addition, embolism in either the petiole or leaf lamina introduces a hydraulic bottleneck between leaf and stem, which would inhibit further water loss from the stem (Zufferey et al. 2011). Therefore, both stomatal closure and $K_{\text {leaf }}$ down-regulation appear to be involved in maintaining $\Psi_{\mathrm{ST}}$ within a safe range, and regulation of $K_{\text {leaf }}$ probably linked $\Psi_{\mathrm{ST}}$ and $g_{\mathrm{s}}$.

\section{Determinants of midday leaf and stem water potentials}

The maintenance of high stem water potential during active transpiration appears to be related to both hydraulic conductivity and stem water storage. The positive correlation between daily reliance on hydraulic capacitance $\left(C_{\text {day }}\right)$ and midday $\Psi_{\mathrm{ST}}$ in this study (Fig. 3) agrees with the positive effects of hydraulic capacitance on $\Psi_{\mathrm{ST}}$ found in previous studies (Meinzer et al.2003, 2008, 2009), suggesting the generality of this coordination, and the importance of stem water storage in maintaining better stem water status during periods of active transpiration. Stem water storage may only contribute a small fraction to the total daily transpiration (Kobayashi \& Tanaka 2001; Phillips et al. 2003; Meinzer et al. 2003); however, it can play an important role in dampening diurnal fluctuations in $\Psi_{\mathrm{ST}}$ (Meinzer et al. 2008). Stem hydraulic conductivity $\left(K_{\mathrm{s}}\right)$ was also correlated with midday $\Psi_{\mathrm{ST}}$, suggesting that the water transport system from root to the stem also plays a role in buffering diurnal fluctuations in stem water status. Therefore, stem water status during periods of active transpiration is a function of 
both the water transport upstream and the transient release of water from internal storage pools.

In contrast to $\Psi_{\mathrm{ST}}$, midday $\Psi_{\mathrm{L}}$ was negatively related to $C_{\text {day }}$ across species: species with higher stem hydraulic capacitance showed more negative midday $\Psi_{\mathrm{L}}$ (Fig. 4a). This was consistent with the negative relationship between daily change in RWC and midday $\Psi_{\mathrm{L}}$ (Fig. $4 \mathrm{~b}$ ) indicating that species withdrawing more stored water from their stems tended to have more negative values of midday $\Psi_{\mathrm{L}}$. This relationship could be explained by an indirect linkage: high $C_{\text {day }}$ allows higher $\Psi_{\mathrm{ST}}$, which promotes maintaining of higher $g_{\mathrm{s}}$, but the greater transpiration associated with higher $g_{\mathrm{s}}$ results in a greater drop in $\Psi$ across the hydraulic resistance of the leaf (Fig. 5b). This relationship also suggests a continuum of different strategies that confer hydraulic safety among plants. Species with high hydraulic capacitance appear to have great reliance on water storage and a relatively risky stomatal strategy, whereas species with low capacitance appear to have relatively strong stomatal control. The relationship between capacitance and $\Psi_{\mathrm{L}}$ observed here is contrary to the result from a study in a Brazilian savanna, which reported a positive relationship between stem hydraulic capacitance and midday $\Psi_{\mathrm{L}}$ (Scholz et al. 2007). This is probably because the study of Scholz et al. was performed during the pronounced dry season when $g_{\mathrm{s}}$ is more depressed at midday, which would bring leaf and stem $\Psi$ closer to equilibrium. In contrast, midday $g_{s}$ of the trees in the present study was relatively high (ranging from 0.08 to $0.34 \mathrm{~mol} \mathrm{~m}^{-2} \mathrm{~s}^{-1}$ ), which would prevent equilibrium between stem and leaf $\Psi$. Partial loss of $K_{\text {leaf }}$ in response to the transpiration-induced decline in $\Psi_{\mathrm{L}}$ would amplify the difference between $\Psi_{\mathrm{ST}}$ and $\Psi_{\mathrm{L}}$ unless transpiration was limited by reduced $g_{\mathrm{s}}$.

\section{Comparison between evergreen and deciduous species}

Evergreen and deciduous species showed convergent relationships between midday $\Psi_{\mathrm{ST}}$ and both stem capacitance and midday $g_{\mathrm{s}}$ (Fig. 3). However, deciduous species were able to maintain higher midday $\Psi_{\mathrm{ST}}$, and higher midday $g_{\mathrm{s}}$ due to their higher $C_{\text {day }}$ and higher $K_{\mathrm{s}}$, compared with the evergreen species (Table 2). This result is consistent with those from a previous study, showing lower wood density and higher capacitance in deciduous species than co-occurring evergreen species (Choat et al. 2005). Capacitance has been reported to be negatively correlated to xylem resistance to embolism (Domec \& Gartner 2001; Pratt et al. 2007; Meinzer et al. 2008), therefore, our results also suggested a difference in strategy between evergreen and deciduous species for maintaining stem hydraulic safety. Deciduous species with high capacitance may rely more on water storage, while evergreen species with low capacitance may rely more on stomatal control and xylem structural features for embolism resistance (Meinzer et al. 2008).

Notably, in spite of higher $\Psi_{\mathrm{ST}}$ and $g_{\mathrm{s}}$, deciduous species showed significantly lower midday $\Psi_{\mathrm{L}}$ than the evergreen species (Table 2), suggesting that higher $\Psi_{\text {ST }}$ does not necessarily result in higher $\Psi_{\mathrm{L}}$, and high $\Psi_{\mathrm{L}}$ is not necessary for maintaining high midday $g_{\mathrm{s}}$ in these species. This agrees with the result that midday $g_{\mathrm{s}}$ was more related to $\Psi_{\text {ST }}$ rather than to $\Psi_{\mathrm{L}}$ across species in the present study. Deciduous species may maintain high $g_{\text {s }}$ during the midday at the expense of embolism in their leaves. Although diurnal embolism was not studied in the present study, deciduous species showed lower midday $K_{\text {leaf }}$ compared to evergreen species (Fig. 4), which, combined with higher midday $g_{s}$ and transpiration rate contributed to substantially lower midday $\Psi_{\mathrm{L}}$ than in evergreen species. In addition, although deciduous species showed significantly higher $C_{\text {day }}, K_{\mathrm{s}}$ midday $\Psi_{\mathrm{ST}}$ and $g_{\mathrm{s}}$ than evergreen species, evergreen and deciduous species showed overlap in these functional traits, suggesting that these two phenological groups operate along a shared continuum of functional traits.

In conclusion, we found that midday $g_{\text {s }}$ was more closely associated with midday stem water status than with leaf water status, suggesting that the functional significance of stomatal regulation in the species studied is likely prevention of stem rather than leaf xylem dysfunction. The ability of species to keep high stem water potential during periods of active transpiration was related to both stem hydraulic conductivity and reliance on stem hydraulic capacitance. Our results also suggest different strategies in coordinating long-distance water transport and stomatal behaviour. Species with high hydraulic capacitance and conductivity appear to have a relatively risky stomatal strategy, whereas species with low capacitance and $K_{\mathrm{s}}$ appear to have relatively strong stomatal control.

\section{ACKNOWLEDGMENTS}

We thank the Ailaoshan Station for Subtropical Forest Ecosystem Studies for logistic support. This research was supported by a National Science Foundation of China grant (30670320).We also would like to thank Mr. Yang Qiuyun, Mr. Zeng Xiaodong, Mr. Ai Ke, Mr. Luo Xin, Mr. Li Xinde and Mr. Liu Yuhong for their assistance in the field work. We thank two anonymous referees for their helpful comments. The authors declare that they have no conflict of interest.

\section{REFERENCES}

Begg J.E. \& Turner N.C. (1970) Water potential gradients in field tobacco. Plant Physiology 46, 343-346.

Brodribb T.J. \& Feild T.S. (2000) Stem hydraulic supply is linked to leaf photosynthetic capacity: evidence from New Caledonian and Tasmanian rainforests. Plant, Cell \& Environment 23, 13811388.

Brodribb T.J. \& Holbrook N.M. (2003) Stomatal closure during leaf dehydration, correlation with other leaf physiological traits. Plant Physiology 132, 2166-2173.

Brodribb T.J. \& Holbrook N.M. (2004a) Diurnal depression of leaf hydraulic conductance in a tropical tree species. Plant, Cell \& Environment 27, 820-827. 
Brodribb T.J. \& Holbrook N.M. (2004b) Stomatal protection against hydraulic failure: a comparison of coexisting ferns and angiosperms. New Phytologist 162, 663-670.

Brodribb T.J., Holbrook N.M., Edwards E.J. \& Gutierrez M.V. (2003) Relations between stomatal closure, leaf turgor and xylem vulnerability in eight tropical dry forest trees. Plant, Cell \& Environment 26, 443-450.

Brodribb T.J., Feild T. \& Jordan G. (2007) Leaf maximum photosynthetic rate and venation are linked by hydraulics. Plant Physiology 144, 1890-1898.

Bucci S.J., Scholz F.G., Goldstein G., Meinzer F.C. \& Sternberg L.D.S.L. (2003) Dynamic changes in hydraulic conductivity in petioles of two savanna tree species: factors and mechanisms contributing to the refilling of embolized vessels. Plant, Cell \& Environment 26, 1633-1645.

Bucci S.J., Scholz F.G., Goldstein G., Meinzer F.C., Hinojosa J.A., Hoffmann W.A. \& Franco A.C. (2004) Processes preventing nocturnal equilibration between leaf and soil water potential in tropical savanna woody species. Tree Physiology 24, 1119-1127.

Campanello P.I., Gatti M.G. \& Goldstein G. (2008) Coordination between water-transport efficiency and photosynthetic capacity in canopy tree species at different growth irradiances. Tree Physiology 28, 85-94.

Choat B., Ball M.C., Luky J.G. \& Holtum J.A.M. (2005) Hydraulic architecture of deciduous and evergreen dry rainforest tree species from north-eastern Australia. Trees 19, 305-311.

Domec J.-C. \& Gartner B.L. (2001) Cavitation and water storage capacity in bole xylem segments of mature and young Douglasfir trees. Trees 15, 204-214.

Franks P.J. \& Farquhar G.D. (1999) A relationship between humidity response, growth form and photosynthetic operating point in C3 plants. Plant, Cell \& Environment 22, 1337-1349.

Franks P.J., Cowan I.R., Tyerman S.D., Cleary A.I., Lloyd J. \& Farquhar G.D. (1995) Guard-cell pressure aperture characteristics measured with the pressure probe. Plant, Cell \& Environment 18, 795-800.

Goldstein G., Andrade J.L., Meinzer F.C., Holbrook N.M., Cavelier J., Jackson P. \& Celis A. (1998) Stemwater storage and diurnal patterns of water use in tropical forest canopy trees. Plant, Cell and Environment 21, 397-406.

Grassi G., Ripullone F., Borghetti M., Raddi S. \& Magnani F. (2009) Contribution of diffusional and non-diffusional limitations to midday depression of photosynthesis in Arbutus unedo L. Trees 23, 1149-1161.

Hacke U.G. \& Sperry J.S. (2003) Limits to xylem refilling under negative pressure in Laurus nobilis and Acer negundo. Plant, Cell \& Environment 26, 303-311.

Iio A., Fukasawa H., Nose Y. \& Kakubari Y. (2004) Stomatal closure induced by high vapor pressure deficit limited midday photosynthesis at the canopy top of Fagus crenata Blume on Naeba mountain in Japan. Trees 18, 510-517.

James S.A., Clearwater M.J., Meinzer F.C. \& Goldstein G. (2002) Heat dissipation sensors of variable length for the measurement of sap flow in trees with deep sapwood. Tree Physiology 22, 277-283.

Johnson D.M., Woodruff D.R., McCulloh K.A. \& Meinzer F.C. (2009a) Leaf hydraulic conductance measured in situ, declines and recovers daily: leaf hydraulics, water potential and stomatal conductance in four temperate and three tropical tree species. Tree Physiology 29, 879-887.

Johnson D.M., Meinzer F.C., Woodruff D. \& McCulloh K.A. (2009b) Leaf xylem embolism, detected acoustically and by cryoSEM, corresponds to decreases in leaf hydraulic conductance in four evergreen species. Plant, Cell \& Environment 32, 828-836.

Johnson D.M., McCulloh K.A., Meinzer F.C., Woodruff D.R. \& Eissenstant D.M. (2011a) Hydraulic patterns and safety margins, from stem to stomata, in three eastern US tree species. Tree Physiology 31, 659-668.

Johnson D.M., McCulloh K.A., Woodruff D.R. \& Meinzer F.C. (2011b) Evidence for xylem embolism as a primary factor in dehydration-induced decline in leaf hydraulic conductance. Plant, Cell \& Environment 35, 760-769.

Kobayashi Y. \& Tanaka T. (2001) Water flow, hydraulic characteristics of Japanese red pine and oak trees. Hydrological Processes 15, 1731-1750.

Koch G.W., Amthor J.S. \& Goulden M.L. (1994) Diurnal patterns of leaf photosynthesis, conductance and water potential at the top of a lowland rainforest in Cameroon: measurements from the Radeu de Cimes. Tree Physiology 14, 347-360.

Kosugi Y. \& Matsuo N. (2006) Seasonal fluctuations and temperature dependence of leaf gas exchange parameters of co-occurring evergreen and deciduous trees in a temperate broad-leaved forest. Tree Physiology 26, 1173-1184.

Lo Gullo M.A., Nardini A., Triflio P. \& Salleo S. (2003) Changes in leaf hydraulic and stomatal conductance following drought stress and irrigation in Ceratonia siliqua (Carob tree). Physiologia Plantarum 117, 186-194.

Meinzer F.C., James S.A., Goldstein G. \& Woodruff D.R. (2003) Whole-tree water transport scales with sapwood capacitance in tropical forest canopy trees. Plant, Cell \& Environment 26, 1147 1155.

Meinzer F.C., Woodruff D.R., Domec J.-C., Goldstein G., Campanello P.I., Gatti M.G. \& Villalobos-Vega R. (2008) Coordination of leaf and stem water transport properties in tropical forest trees. Oecologia 156, 31-41.

Meinzer F.C., Johnson D.M., Lachenbruch B., McCulloh K.A. \& Woodruff D.R. (2009) Xylem hydraulic safety margins in woody plants: coordination of stomatal control of xylem tension with hydraulic capacitance. Functional Ecology 23, 922 930.

Melcher P.J., Goldstein G., Meinzer F.C., Yount D., Jones T., Holbrook N.M. \& Huang C.X. (2001) Water relations of coastal and estuarine Rhizophora mangle: xylem tension and dynamics of embolism formation and repair. Oecologia 126, 182-192.

Nardini A., Tyree M.T. \& Salleo S. (2001) Xylem cavitation in the leaf of Prunus laurocerasus and its impact on leaf hydraulics. Plant Physiology 125, 1700-1709.

Nardini A., Lo Gullo M.A. \& Salleo S. (2011) Refilling embolized xylem conduits: is it a matter of phloem unloading? Plant Science 180, 604-611.

Phillips N.G., Ryan M.G., Bond B.J., McDowell N.G., Hinckley T.M. \& Cermák J. (2003) Reliance of stored water increases with tree size in three species in the Pacific Northwest. Tree Physiology 23, 237-245.

Pratt R.B., Jacobsen A.L., Ewers F.W. \& Davis S.D. (2007) Relationships among xylem transport, biomechanics and storage in stems and roots of nine Rhamnaceae species of the California chaparral. New Phytologist 174, 787-798.

Qiu X.-Z. \& Xie S.-C. (1998) Studies on the Forest Ecosystem in Ailao Mountains Yunnan, China. Yunnan Science and Technology Press, Kunming.

Raschke K. \& Resemann A. (1986) The midday depression of CO2assimilation in leaves of Arbutus unedo L.: diurnal changes in photosynthetic capacity related to changes in temperature and humidity. Planta 168, 546-558.

Sack L., Melcher P.J., Zwieniecki M.A. \& Holbrook N.M. (2002) The hydraulic conductance of the angiosperm leaf lamina: a comparison of three measurement methods. Journal of Experimental Botany 53, 2177-2184.

Sack L., Cowan P.D. \& Holbrook N.M. (2003) The major veins of mesomorphic leaves revisited: tests for conductive overload in 
Acer saccharum (Aceraceae) and Quercus rubra (Fagaceae). American Journalof Botany 90, 32-39.

Santiago L.S., Goldstein G., Meinzer F.C., Fisher J.B., Machado K., Woodruff D. \& Jones T. (2004) Leaf photosynthetic traits scale with hydraulic conductivity and wood density in Panamanian forest canopy trees. Oecologia 140, 543-550.

Scholz F.G., Bucci S.J., Goldstein G., Meinzer F.C., Franco A.C. \& Miralles-Wilhelm F. (2007) Biophysical properties and functional significance of stem water storage tissues in neotropical savanna trees. Plant, Cell \& Environment 30, 236-248.

Schulze E.-D., Lange O.L., Evenari M., Kappen L. \& Buschbom U. (1974) The role of air humidity and leaf temperature in controlling stomatal resistance of Prunus armeniaca L. under desert conditions. I. A simulation of daily course of stomatal resistance. Oecologia 17, 159-170.

Sellin A. \& Kupper P. (2007) Temperature, light and leaf hydraulic conductance of little-leaf linden (Tilia cordata) in a mixed forest canopy. Tree Physiology 27, 679-688.

Tenhunen J.D., Pearcy R.W. \& Lange O.L. (1987) Diurnal variations in leaf conductance and gas exchange in natural environments. In Stomatal Function (eds E. Zeiger, G.D. Farquhar \& I.P. Cowan), pp. 323-351. Stanford University Press, Stanford.

Tucci M.L.S., Erismann N.M., Machado E.C. \& Ribeiro R. (2010) Diurnal and seasonal variation in photosynthesis of peach palms grown under subtropical conditions. Photosynthetica 48, 421429.

Tyree M.T. \& Sperry J.S. (1989) Vulnerability of xylem to cavitation and embolism. Annual Review of Plant Physiology and Molecular Biology 40, 19-38.
Woodruff D.R., Mcculloh K.A., Warren J.M., Meinzer F.C. \& Lachenbruch B. (2007) Impacts of tree height on leaf hydraulic architecture and stomatal control in Douglas-fir. Plant, Cell and Environment 30, 559-569.

Yang S.D. \& Tyree M.T. (1993) Hydraulic resistance in Acer saccharum shoots and its influence on leaf water potential and transpiration. Tree Physiology 12, 231-242.

Zhang J.-L. \& Cao K.-F. (2009) Stem hydraulics mediates leaf water status, carbon gain, nutrient use efficiencies and plant growth rates across dipterocarp species. Functional Ecology 23, 658-667.

Zhang Y.-J., Meinzer F.C., Hao G.-Y., et al. (2009) Size-dependent mortality in a Neotropical savanna tree: the role of heightrelated adjustments in hydraulic architecture and carbon allocation. Plant, Cell \& Environment 32, 1456-1466.

Zufferey V., Cochard H., Ameglio T., Spring J.L. \& Viret O. (2011) Diurnal cycles of embolism formation and repair in petioles of grapevine (Vitisvinifera cv. Chasselas). Journal of Experimental Botany 62, 3885-3894.

Zwieniecki M.A. \& Holbrook N.M. (1998) Diurnal variation in xylem hydraulic conductivity in white ash (Fraxinus Americana L.), red maple (Acer rubrum L.) and red spruce (Picea rubens Sarg.). Plant, Cell \& Environment 21, 11731180.

Zwieniecki M.A. \& Holbrook N.M. (2009) Confronting Maxwell's demon: biophysics of xylem embolism repair. Trends in Plant Science 14, 530-534.

Received 9 April 2012; received in revised form 13 June 2012; accepted for publication 14 June 2012 